\title{
Isolation of Bacteriophage from Starter Cultures of Yoghurt and Formulation of a Phage-resistant Starter Culture
}

\author{
Gayani Weerasinghe ${ }^{1 *}$, Sanath Hettiarachi ${ }^{1}$, Kumara Jayarathne ${ }^{2}$ \\ ${ }^{I}$ Dept: of Biological Science, Faculty of Applied Science, Rajarata University of Sri Lanka, Sri Lanka \\ ${ }^{2}$ MILCO Dairy Factory, Narahenpita, Sri Lanka \\ Corresponding Author:*gayani260@yahoo.com
}

\begin{abstract}
Yoghurt is the best known of all cultured-milk products, and the most popular almost all over the world. For the manufacturing of yoghurt, bacterial cultures known as starters are used. Bacteriophage attacks during the production causes loss of entire batches of yoghurt resulting in economic losses to the company. Culture bacteria (Streptococcus thermophilus \& Lactobacillus bulgaricus) in starter cultures (Direct Vat Set-DVS) were isolated using Eliker medium. Bacteriophage was isolated from affected yoghurt using M-17 liquid, semisolid and solid culture media and that isolated bacteriophage attacked Lb. bulgaricus but not St. thermophilus. After further confirmation of phage attack using the setting delay of yoghurt, starter cultures that are used in MILCO Company were tested to find out resistant and susceptible varieties. Hence by using resistant strain of St. thermophilus and Lb. bulgaricus new starter culture was prepared and yoghurt samples were reset with different concentrations of culture bacteria in 1:1 ratio. Each yoghurt sample was tested for its setting time, rate of acidity increase and $\mathrm{pH}$ decrease to investigate proper concentration of culture bacteria which have to be mixed and the best amount was 1.5 $\mathrm{ml}$ from each culture bacteria at $10^{7} \mathrm{CFU} / \mathrm{ml}$ per $80 \mathrm{ml}$ of milk.
\end{abstract}

Keywords: Eliker Medium, M-17 Medium, Lactobacillus bulgaricus, Streptococcus thermophilus

\section{Introduction}

Milk is defined to be the lacteal secretion, practically free from colostrums, obtained by the complete milking of one or more healthy cows, five days after and fifteen days before parturition (Host, 1994; Attia et al., 2001). Raw milk undergoes with the pasteurization process before using for any production.

Yoghurt is a popular dairy product almost all over the world and for the manufacturing of yoghurt, bacterial cultures known as starters are used. Quality of starter culture is the most important factor that influences the development of quality yoghurt (Asmahan, 2011). The starter is added to the product and allowed to grow there under controlled conditions. Different cultures have different characteristics and therefore various types of cultures are used. For the production of yoghurt, thermophillic bacteria culture is used and it consists with Streptococcus thermophillus and Lactobacillus bulgaricus. Most yoghurt has a ratio of cocci to bacilli between 1:1 and 2:1. The bacilli must never be allowed to gain the upper hand, as the flavor will then be too acid.

The optimum temperature for inoculation in yoghurt manufacture is $43^{\circ} \mathrm{C}$ to achieve a cocci-to-bacilli ratio of $1: 1$, with a rate of inoculums of $2.5-3 \%$ and an incubation time of $2.5-3$ hours. According to the Sri Lankan Standard (SLS 824: 1989) for fermented milk products, yoghurt is a fermented milk product obtained from coagulation of the agency of organisms of St. thermophillus and Lb. bulgaricus.

Bacteriophages or, simply, phages are ubiquitous (Wommack and Colwell, 2000) and bacterial parasitic viruses and which cause damages in yoghurt production. Phage infection represents the most significant biological factor affecting industries that rely on bacterial growth and metabolic activities. Depending on the process stage 
in which the infection proceeds, consequences may vary from slow acid production to completely lost batches. According to Mariángeles et al., (2012) high pH values, high residual lactose concentration and insufficient lactic acid content are the result of phage attacks occurring during the early stages of the fermentation. He further explains that, the residual lactose might be the substrate for the growth and metabolic activity of spoilage bacteria that negatively affect the quality of the product.

Bacteriophage attacked of starter cultures of yoghurt may have the characteristics of setting delay, uneven setting of yoghurt and ropiness of yoghurt. In the non-sterile environment of raw or heat-treated milk, the added Lactic Acid Bacteria (LAB) cells will come into contact with virulent phages found in milk (Émond and Moineau, 2007). Although phage concentration is usually low in milk, a specific phage population can increase rapidly if phage-sensitive cells are present in the starter culture.

\section{Materials and Methodology}

\section{Sample Collection}

This experiment was done during the period of April 2012 - April 2014 in MILCO dairy milk factory, Colombo, Sri Lanka and sampling was done from their yoghurt processing line.

\section{Isolation of culture bacteria of DVS cultures (Lb. bulgaricus and St. thermophilus)}

Eliker media was used for selection and differentiation of Lb. bulgaricus and St. thermophillus in DVS cultures. Liquid DVS culture solution was prepared and $1 \mathrm{~mL}$ of was pipette out from $10^{-3}$ and poured into a sterilized Petri dish and mixed with Eliker media and incubated at $44{ }^{\circ} \mathrm{C}$ of temperature for $48 \mathrm{hrs}$. Two types of bacterial colonies were appeared in Eliker plates and according to its size they were differentiated and for further confirmation Gram staining was carried out.

\section{Isolation of bacteriophage from yoghurt starter culture}

To the identification of bacteriophage attack of yoghurt cultures, M-17 media were used as liquid, semi solid and solid types and several suspected yoghurts were sampled from the processing line. Culture bacteria were inoculated into M-17 liquid medium and kept for incubation $24 \mathrm{hrs} / 44{ }^{\circ} \mathrm{C}$. Selected yoghurt samples were diluted up to $10^{-5}$ with peptone water and $1 \mathrm{~mL}$ was pipette out from each dilution factor and poured into sterilized Petri dish. Molted solid type M-17 media was added into it and kept for five- six hours for solidification. After that period $1 \mathrm{~mL}$ of each culture bacterial samples which were inoculated into liquid M-17 media was pipette out and transferred into semi solid M-17 media. $1 \mathrm{~mL}$ of this solution was pipette out and poured into previously prepared solid M-17 plates as the top layer and kept for solidification and incubated in 30 ${ }^{0} \mathrm{C} / 24$ hrs.

\section{Further confirmation of bacteriophage attack of yoghurt samples}

According to the results in M-17 plates, DVS-CUL-5 is positive for the bacteriophage attack. It was further confirmed by testing their setting time with different volumes of culture bacteria and isolated bacteriophage. Culture bacteria and bacteriophage were mixed according to following volumes of Table 1 to determine the setting time of each yoghurt samples. 
Table 1: Volumes of culture bacteria and isolated bacteriophage mixed to determine the setting time of yoghurt samples

\begin{tabular}{llll}
\hline Sample & $\begin{array}{l}\text { Amount of } L b . \text { bulgaricus } \\
\text { culture } / \mathrm{mL}\end{array}$ & $\begin{array}{l}\text { Amount of St. thermophilus } \\
\text { culture } / \mathrm{mL}\end{array}$ & $\begin{array}{l}\text { Amount of bacteriophage } \\
\text { culture/ } \mathrm{mL}\end{array}$ \\
\hline $\mathbf{A}$ & 1.0 & 1.0 & - \\
\hline $\mathbf{A}-\mathbf{1}$ & 1.0 & 1.0 & 1.0 \\
\hline $\mathbf{B}$ & 2.0 & 2.0 & - \\
\hline $\mathbf{B}-\mathbf{1}$ & 2.0 & 2.0 & 2.0 \\
\hline $\mathbf{C}$ & 3.0 & 3.0 & - \\
\hline $\mathbf{C}-1$ & 3.0 & 3.0 & 3.0 \\
\hline
\end{tabular}

\section{Identification of resistible and susceptible DVS culture types for isolated bacteriophage}

Milco dairy factory used three DVS culture types, DVS-CUL-5, DVS-CUL-6 and DVS-CUL-7 and vary according to the sub species level of culture bacteria. Isolated bacteriophage was cultured in M-17 plates and was sucked separately and dissolved in autoclaved peptone water. Liquid DVS culture types were prepared by dissolving one milligram of culture powder in ten milliliters of peptone water. One milliliter of bacteriophage solution was added into ten milliliters of each DVS culture types and stored in $44{ }^{0} \mathrm{C}$ of temperature. TCC procedure was carried throughout the storage period of five days.

\section{Resetting of yoghurt samples using the culture bacteria which resist to bacteriophage}

Liquid culture media was prepared using those resistance sub species of Lb. bulgaricus in DVS-CUL-6 and St. thermophilus in DVS-CUL-5. To concentrate bacterial cells centrifuging was carried out and re-dissolved them using distilled water. Different volumes of two bacterial species were mixed according to 1:1 ratio to reset a yoghurt sample as in Table 2.

Table 2: Different volumes of Lb. bulgaricus and St. thermophilus used prepare phage-resistant yoghurt culture

\begin{tabular}{lll}
\hline Sample & $\begin{array}{l}\text { Amount of Lb. bulgaricus } \\
\text { culture } / \mathrm{mL}\end{array}$ & $\begin{array}{l}\text { Amount of St. thermophilus } \\
\text { culture } / \mathrm{mL}\end{array}$ \\
\hline Sample A & 1.0 & 1.0 \\
\hline Sample B & 1.5 & 1.5 \\
\hline Sample C & 2.0 & 2.0 \\
\hline Sample D & 2.5 & 2.5 \\
\hline Sample E & 3.0 & 3.0 \\
\hline Sample A & 1.0 & 1.0 \\
\hline
\end{tabular}

Setting time of each yoghurt sample was measured to find out the best proportion and amount of culture bacteria. Meanwhile acidity and $\mathrm{pH}$ values were also monitored from just after the incubation to twenty days of storage. Sample which takes long period of days to exceed the standard acidity and $\mathrm{pH}$ values, can be considered as the better sample than the others. In addition to all those factors, results of the sensory panel were also used to determine the best yoghurt sample. 


\section{Results and Discussion}

\section{Isolation of culture bacteria of DVS cultures (Lb. bulgaricus and St. thermophilus)}

Both colonies in Eliker plates were circular shaped but with different colours. Small sized are creamy grey and another one is little bit of large with creamy white colour and simple staining procedure differential their cell shape as rod and spherical. Gram staining confirmed them as Gram positive bacteria.

\section{Isolation of bacteriophage from yoghurt starter culture}

Presence of bacteriophage in yoghurt samples of DVS-CUL-5 was confirmed by visualizing clear zone areas around the Lb. bulgericus cells in M-17 agar plates as shown in Figure 1. Around the St. thermophilus colonies such clear zones were not observed (Figure 12). Isolated bacteriophage only affected Lb. bulgaricus and not St. thermophilus indicating its resistance to the particular phage.
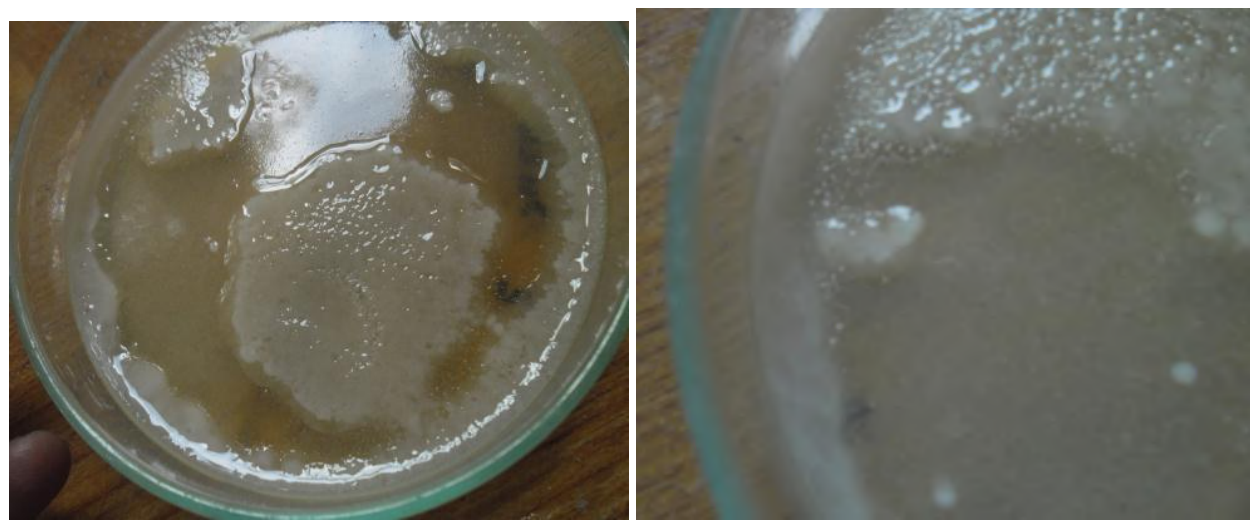

Figure 1: Clear zones around the Lb. bulgaricus colonies in M-17 plates
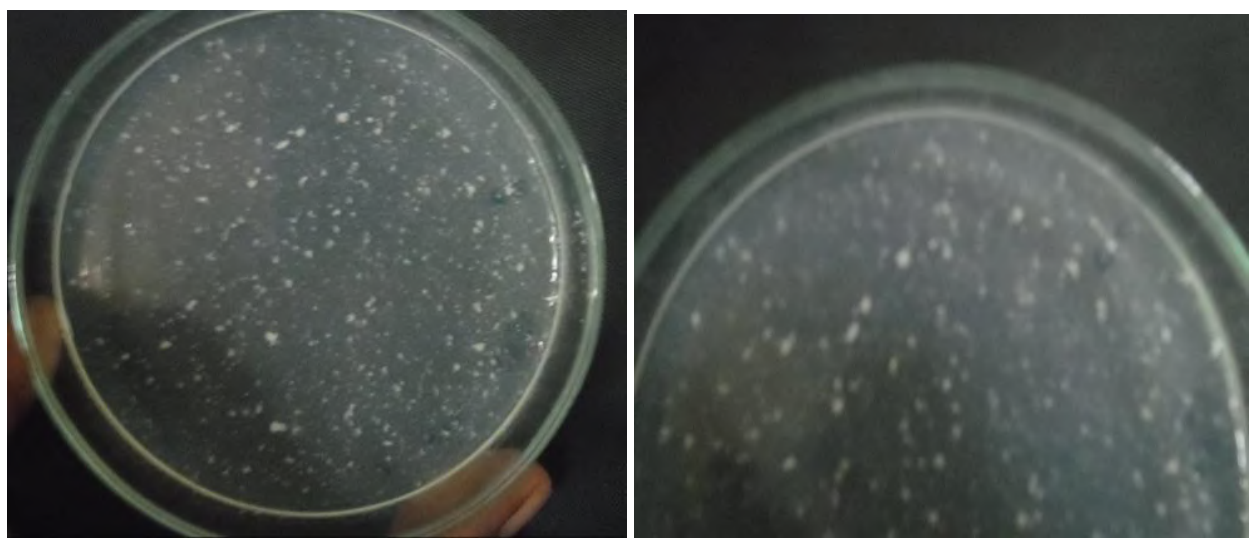

Figure 2: St. thermophilus colonies in M-17 plates without clear zones

\section{Further confirmation of bacteriophage attack of yoghurt samples}

For further confirmation of this phage attack, setting time of yoghurt samples was observed by mixing culture bacteria and the isolated phage separately. According to the results in Table 3, there is a setting delay in yoghurt samples with bacteriophage rather than the samples without phage. 
Table 3: Variation of setting time of yoghurt samples with and without of bacteriophage and different volumes of culture bacteria

\begin{tabular}{lll}
\hline $\begin{array}{l}\text { Bacteriophage Negative } \\
\text { samples }\end{array}$ & Bacteriophage positive samples & Setting time (hr) \\
\hline Sample A & Sample A-1 & $5 \mathrm{hr} 48 \mathrm{~min}$ \\
\hline & & $7 \mathrm{hr} 11 \mathrm{~min}$ \\
\hline Sample B & Sample B-1 & $6 \mathrm{hr} 01 \mathrm{~min}$ \\
\hline & & $6 \mathrm{hr} 07 \mathrm{~min}$ \\
\hline Sample C & Sample C-1 & $5 \mathrm{hr} 13 \mathrm{~min}$ \\
\hline
\end{tabular}

In Sample A, setting time recorded as $5 \mathrm{hr} 48 \mathrm{~min}$ and when it combined with the bacteriophage in Sample A-1 there is a delay on its setting time $(7 \mathrm{hr} 11 \mathrm{~min})$. Same happened in sample B, which has $5 \mathrm{hr} 01 \mathrm{~min}$ of period without the bacteriophage and with the inoculation of phage in Sample B-1 it took long period for setting (6 hr $07 \mathrm{~min}$ ). In Sample C (without page inoculation) there was $4 \mathrm{hr} 13 \mathrm{~min}$ of setting period and bacteria results and in Sample C-1 (with bacteriophage) it extended up to $5 \mathrm{hr} 28 \mathrm{~min}$. So setting delay of yoghurt samples was observed when they are treated with the isolated bacteriophage. Due to the bacteriophage attack of $L b$. bulgaricus, unbalanced bacterial ratio was resulted and affect on setting time.

\section{Identification of resistant and susceptible DVS culture types for isolated bacteriophage}

Culture bacterial counts were resulted as in Table 4, when mixed with particular bacteriophage.

Table 4: Variation of TCC of each bacterium in three different cultures

\begin{tabular}{lllllll}
\hline Day & \multicolumn{2}{c}{ CUL5 $* 10^{3}$} & \multicolumn{2}{c}{ CUL7 $* 10^{3}$} & \multicolumn{2}{c}{ CUL6 *10 } \\
& L.b & S.t & L.b & S.t & L.b & S.t \\
\hline Just after incubation & 13.3 & 14.3 & 14.3 & 15.3 & 12.6 & 12.0 \\
\hline 1 & 12.6 & 14.0 & 14.0 & 15.3 & 12.3 & 12.0 \\
\hline 2 & 10.3 & 13.3 & 11.6 & 15.0 & 11.0 & 11.6 \\
\hline 3 & 8.3 & 14.3 & 9.0 & 14.3 & 12.0 & 11.3 \\
\hline 4 & 5.3 & 13.0 & 7.0 & 14.3 & 12.3 & 11.3 \\
\hline 5 & 3.6 & 14.0 & 5.3 & 15.0 & 12.6 & 12.0 \\
\hline
\end{tabular}

\section{L.b - Lb. bulgaricus, S.t - St. thermophilus}

Lb. bulgaricus count reduced in DVS-CUL-5 and DVS-CUL-7 when it mixed with bacteriophage. However, St. thermophilus in above cultures is not susceptible for phage attack. DVS-CUL-6 is not susceptible for phage attack but the company is not preferred to use it due to its variations in quality. By mixing of St. thermophilus from DVS-CUL-5 and resistant Lb. bulgaricus from DVS-CUL-6, new type of starter culture (DVS-CULNEW) which resistant to particular bacteriophage was prepared. Those strains were mixed in different volumes to reset a yoghurt sample as follows and their setting time was recorded as in Table 5. 
Table 5: Setting time of yoghurt samples after mixing of liquid culture bacteria in different volumes

\begin{tabular}{ll}
\hline Sample & Setting time \\
\hline Sample A & $4 \mathrm{hr} 35 \mathrm{~min}$ \\
\hline Sample B & $4 \mathrm{hr} 10 \mathrm{~min}$ \\
\hline Sample C & $4 \mathrm{hr} 00 \mathrm{~min}$ \\
\hline Sample D & $3 \mathrm{hr} 20 \mathrm{~min}$ \\
\hline Sample E & $3 \mathrm{hr} 10 \mathrm{~min}$ \\
\hline
\end{tabular}

In addition to the setting time, variation of acidity and $\mathrm{pH}$ values of each yoghurt samples throughout its storage period is recorded in Figure $3 \mathrm{a}$ and Figure $3 \mathrm{~b}$.

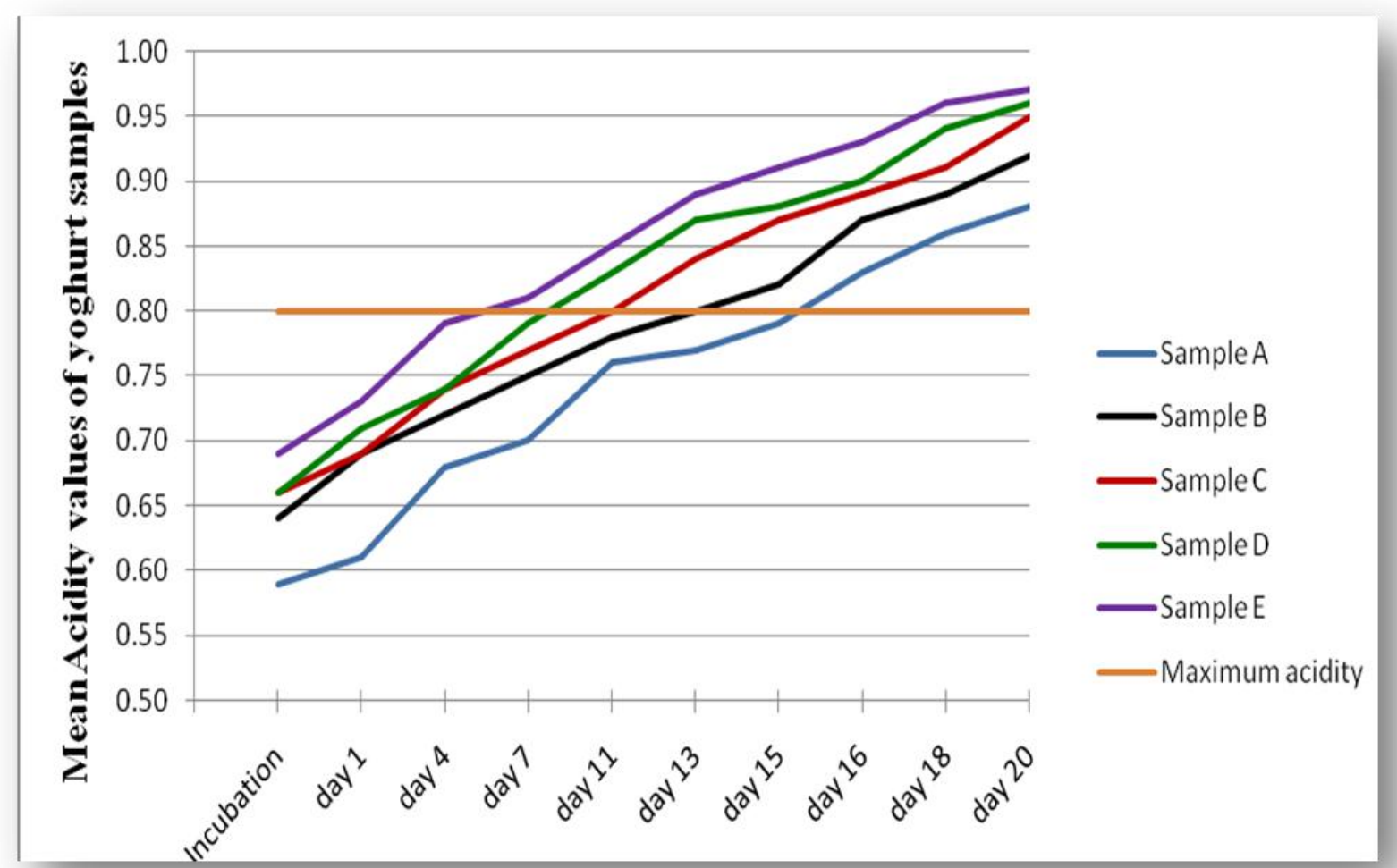

Figure 3a: Variation of acidity value of yoghurt samples throughout its storage period of twenty days $\left(>10^{\circ} \mathrm{C}\right)$ 


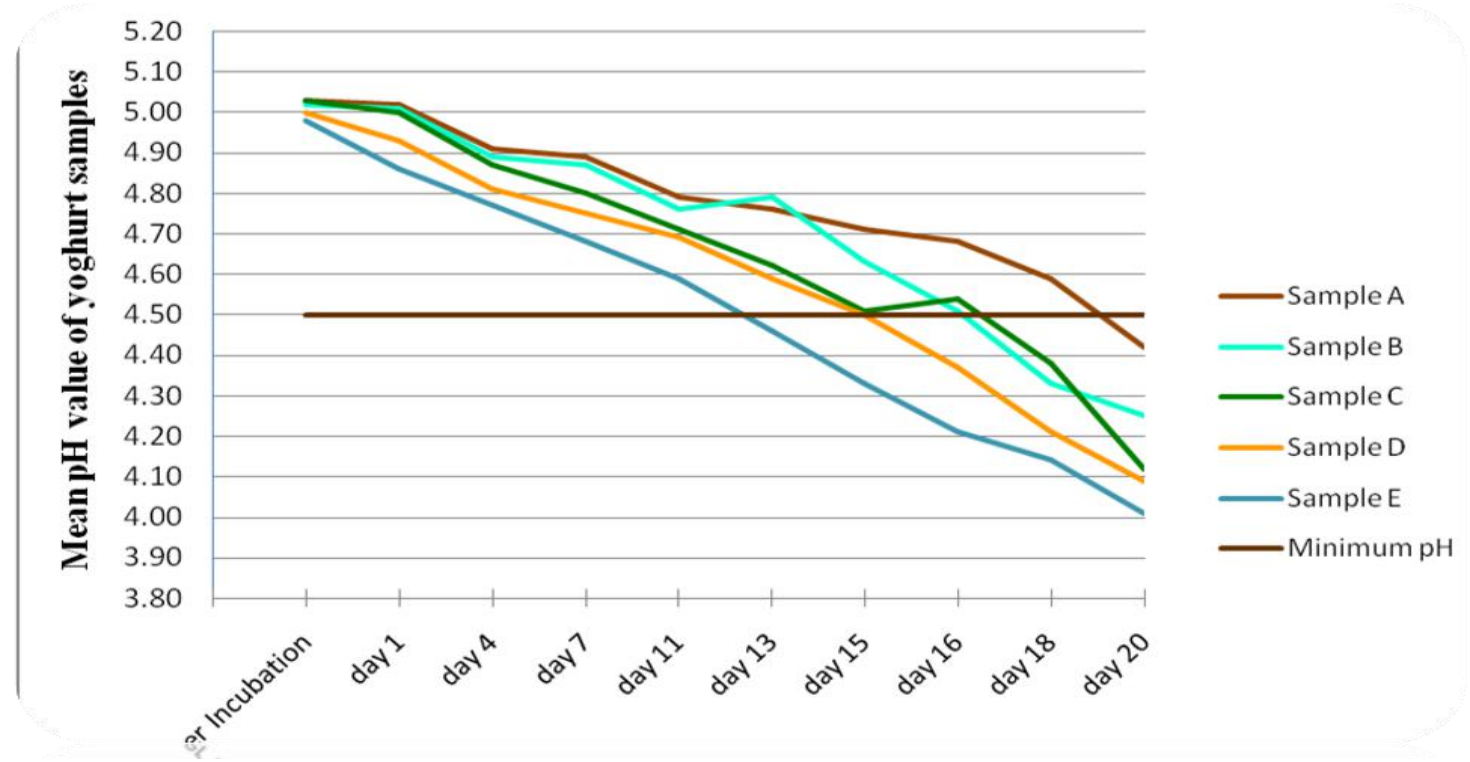

Figure 3b: Variation of pH value of yoghurt samples throughout its storage period of twenty days $\left(>10^{\circ} \mathrm{C}\right)$

Sample E has the minimum setting period ( $3 \mathrm{hr} 10 \mathrm{~min}$ ) but its acidity was in higher value (0.69) just after the incubation. Five samples (Sample A, B, C, D and E) again subjected to measuring of acidity and $\mathrm{pH}$ values throughout the storage period. Standard $\mathrm{pH}(4.50)$ and acidity values $(0.80)$ were overcome by sample B in its fifteenth day of storage. By considering with acidity, $\mathrm{pH}$ and setting time, the most suitable one is Sample B which made from mixing of phage resistant culture bacteria in 1:1 ration with the volume of $1.5 \mathrm{~mL}$ from each. Variation of sensory attributes such as smell, appearance, texture and overall acceptability of five yoghurt samples throughout twenty days are listed in Figure 3c.

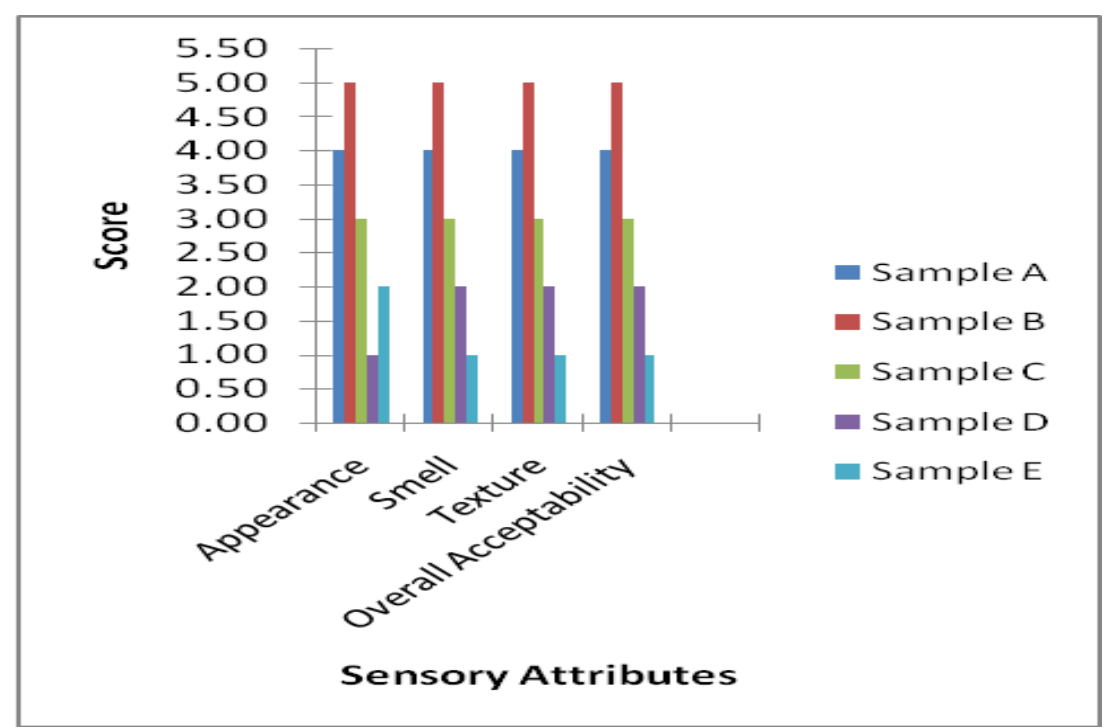

Figure 3c: Variation of sensory attributes of yoghurt samples throughout its storage period of twenty days (>10 $\left.{ }^{0} \mathrm{C}\right)$

Results indicated sample B, with average setting time of $4 \mathrm{hr} 10 \mathrm{~min}$ and in just after the incubation there is 0.64 acidity and $5.02 \mathrm{of} \mathrm{pH}$ and best with highest values for sensory parameters.

Sample B > Sample A > Sample C > Sample D > Sample E 


\section{Conclusion}

Bacteriophage attacks for the yoghurt starter culture was identified in MILCO dairy company and just attacked to $L b$. bulgaricus. Out of three cultures already two were susceptible for phage attack and phage resistant starter culture was produced by using resistant bacterial strains of Lb. bulgaricus and St. thermophilus. Better quality yoghurt without phage attack was reset by mixing them in 1:1 ratio with the volumes of $1.5 \mathrm{~mL}$ of each.

\section{References}

Arimi, S. M., Ryser, E. T., Pritchard, T. J. and Donnelly, C. W. 1997. Diversity of Listeria ribotypes from dairy cattle, silage and dairy processing environments. Journal of Food Protection. 60: 811-816.

Asmahan, A. A. 2011. Isolation and Identification of Lactic Acid Bacteria Isolated from Traditional Drinking Yoghurt in Khartoum State, Sudan. Journal of Bacteriology, 4: 16-22.

Attia, H., Kerouatou, N. and Dhouib, A. 2001. Dromedary milk lactic acid fermentation: Microbiological and rheological characteristic. Industrial Microbiology and Biotechnology. 26(5): 263-270.

Atamer, Z., Dietrich, J., Neve, H., Heller, K. J. and Hinrichs, J. 2010. Influence of the suspension media on the thermal treatment of mesophilic lactococcal bacteriophages. Industrial Journal of Food Microbiology. 20: 408414.

Barbano, D. M., Ma, Y. and Santos, M. V. 2006. Influence of raw milk quality on fluid milk shelf life. Journal of Dairy Science. 89: 9-15.

Badis, A., Guetarni, D., Moussa, B., Henni, D. E. and Kihal, M. 2004. Identification and technological properties of lactic acid bacteria isolated from raw goat's milk of four Algerian races. Journal of Food Micribiology. 21: 579-588.

Briggiler, M. M., Capra, M. L., Quiberoni, A., Vinderola, G., Reinheimer, J. A. and Hynes, E. 2007. Nonstarter Lb. strains as adjunct cultures for cheese making: in vitro characterization and performance in two model cheeses. Journal of Dairy Science. 90: 4532-4542.

Elisabet, W., Wilhelm T. and Marie L. 2002. Prevalence and fingerprinting of Listeria monocytogenes strains isolated from raw whole milk in farm bulk tanks and in dairy plant receiving tanks. Journal of Applied and Environmental microbiology. 7(2): 3366-3370.

Émond, E. and Moineau, S. 2007. Bacteriophages in food fermentations. (Caister Academic Press. Norfolk). 93124.

Fooks, L. J., Fuller, R. and Gibson, G. R.M. 1999. Prebiotics, probiotics and human gut microbiology. Journal of Dairy Science. 9: 53-61.

Gouranga, C. C., Gazi, M. N. U., Aparna, D., Tahmina, B., Sharmin, C. and Basir, U. 2008. Microbiological profile of the traditionally collected industrial raw milk from the milk pocket zones of Bangladesh. Bangladesh Journal Microbiol, 25(1): 17-20.

Griffiths, M. H., Phillips, J. D., West, I. G. and Muir, D. D. 1988. The effect of extended low-temperature storage of raw milk on the quality of pasteurized and UHT milk. Food Microbiology, 5(2): 75-78.

Grimaud, G., Sserunjogi, M. L. and Grillet, N. 2007. An evaluation of milk quality in Uganda, value chain assessment and recommendations. African Journal of Food Agriculture Nutrition and Development. 7(5): 716728.

Guessas, B. and Kihal, M. 2004. Characterization of lactic acid bacteria isolated from Algerian arid zone raw goats milk. African Journal of Biotechnology.3: 339-342.

Høst, A. 1994. Cow's milk protein allergy and intolerance in infancy, some clinical, epidemiological and immunological aspects. Pediatric Allergy and Immunology. 5: 5-36.

Mariángeles, B. M., Sylvain, M. and Andrea, Q. 2012. Bacteriophages and dairy fermentations. Journal of Dairy Science. 2(3): 149-158.

Wommack, K. E. and Colwell, R. R. 2000. Virioplankton: viruses in aquatic ecosystems. Journal of Microbiology and Molecularbiology. 64: 69-114. 